\title{
Best practice in measuring the impact of marketing on brand equity and corporate profitability
}

\author{
RECEIVED: 6 MARCH, 2000 \\ David Haigh \\ Brand Finance plc, Regal House, 70 London Road, Twickenham TWI 3QS. \\ Tel: +44 (0)20 8607 0300; Fax: +44 (0)20 8607 030I; \\ e-mail: d.haigh@brandfinance.com
}

\begin{abstract}
David Haigh qualified as a

Chartered

Accountant with Price Waterhouse in London. $\mathrm{He}$ has worked in international financial management and the marketing services sector, launching Brand Finance in 1996. $\mathrm{He}$ is a fellow of the UK Chartered Institute of Marketing and was a member of the 1998 IPA

Advertising

Effectiveness

Awards judging panel.
\end{abstract}

\begin{abstract}
Marketing plays an increasingly important role in business today. The measurement of marketing activities is still a relatively new field and, as recent reports by the IPA and Brand Finance have indicated, the relationship between marketing and finance departments is still somewhat tenuous. Brand valuations can identify the real financial value of marketing and draw the two disciplines together through greater accountability. A review of the various valuation methods and their robustness is required, while consideration of the independence of valuation experts is needed before deciding on a brand valuation method appropriate for a transparent end result.
\end{abstract}

\section{INTRODUCTION}

Marketing is usually a great expense to a company. Despite this fact, marketing accountability is a relatively new concern. Historical attempts to measure the impact and success of marketing activity were flawed and did not withstand financial criticism. Now, using the brand as the focal point, robust valuation methods allow companies to monitor the success or otherwise of marketing support. Previously alien to each other, the correlation and increasing cooperation between both the marketing and finance departments reflect this development.

Marketing is certainly recognised today as a key driver of business value. The Brand Finance Report 1999 examines City analysts' opinion of marketing and brand information. It reveals a strong demand for marketing information motivated by the need to realise the full value of the company and its potential for growth.

Marketing has always been considered the 'fall guy' when economic conditions deteriorate, as evidenced by the IPA Finance Director Surveys in 1996 and again in 2000. Although very gradual, this view is changing. Companies are slowly beginning to realise that brand and marketing support should not be compromised if long-term health is to be maintained. Through the generation of a strong 
Figure 1: When reviewing a company's performance how useful is each of the following pieces of information

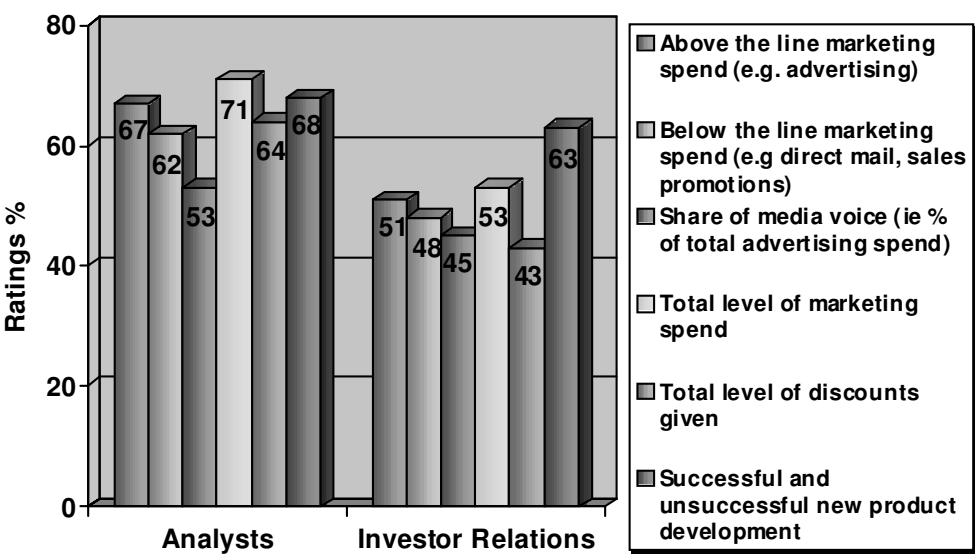

(C)Brand Finance plc

brand, demand can be stabilised and greater volumes, price or a combination of both are possible. Even in markets traditionally driven by price or service specification, branding has developed into a major business tool reflecting its value on sales or price uplift. As evidenced by the author's company's research, City analysts now recognise the bottom-line benefits of a strong brand. As such, brand and marketing accountability needs to improve to satisfy analysts' demands for greater transparency and accountability in this area.

A range of measures determines the effectiveness of marketing. Obviously, each marketing strategy is designed to have a particular impact and fulfil presupposed targets but how does one determine the impact on overall profitability of the entire marketing cause?

\section{WHAT THE CITY WANTS}

Figure 1 identifies the increasing demand by City analysts for marketing information. It illustrates the increasing need to identify marketing spend and activities. In determining investments, analysts are turning to marketing spend and activities as determinants of future growth and profitability.

A report by the IPA year 2000 Finance Director Survey reveals the attitudes of top UK company finance directors towards their marketing colleagues. The study identifies that finance directors increasingly want more and more detailed information about marketing expenditure and 
Figure 2: With regard to the new accounting standards for brands, please indicate to what extent you agree with the following:
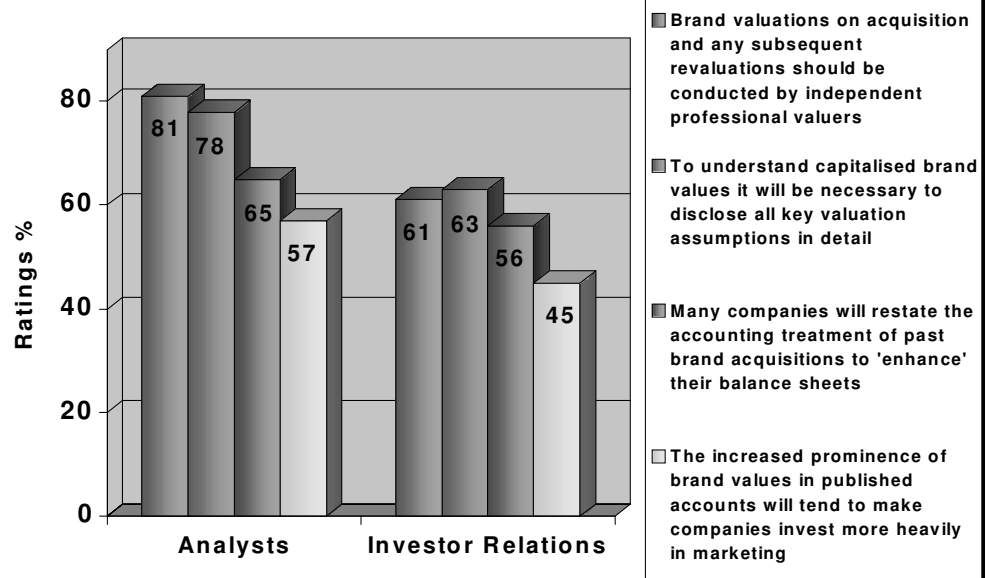

(C)Brand Finance plc

results. According to this research, 56 per cent of finance directors attempt to measure the effectiveness of overall marketing spend and, while 60 per cent of finance directors agree that marketing managers are increasingly financially literate, only 18 per cent believe that it is easy to measure the effectiveness of the marketing effort. Interestingly, only 40 per cent of finance directors believe that marketing managers are able to discuss their plans on a 'return on investment' basis. The results prove that although progress towards a closer integration of marketing and finance is happening there is in general still a long way to go to bridge the gap between the disciplines.

The debate concerning the finan- cial accountability of marketing data is partly both a cause and result of the accounting debate leading to the introduction of Financial Reporting Standard 10 (FRS 10). The standard states that acquired intangible assets must be capitalised, as opposed to the previously accepted method of writing the assets off against reserves. FRS 10 was introduced in late 1998 and clearly states that companies must identify intangible assets, such as brands, on their balance sheet.

The Brand Finance Report 1999 studied the views of City analysts and investor relations directors concerning FRS 10 and its implications for brands. Figure 2 reveals an insight into the impact analysts believe FRS 10 will have. 
The fact that City analysts and internal finance departments desire more information about marketing expenditure and activities highlights the continued rise of brands and marketing up the corporate agenda. It has yet to result in an increase in the number of marketing people at board level. Recent action by the relevant institutional bodies should, however, encourage adjustment from the present heavy bias towards the financial disciplines.

Brands are increasingly recognised as bottom-line contributors. Their impact on sales and maintaining a steady relationship with consumers are imperative to the survival of a company in recession. The Brand Finance Report indicates that both analysts and investor relations directors believe that strong brands can maintain or increase market share in times of economic downturn.

\section{BRAND VALUATION}

Brand values reflect all marketing support and are a topic of heated discussion. The differing opinions on how to value a brand and who should be doing the valuation have created battalions of brand value armies differentiated only by their methods. At least consensus has been reached that brands are valuable and a measurement should be placed on them.

Valuations can be conducted in a number of ways; below are brief definitions of some of the most commonly used:
- cost-based valuations: it is possible to value a brand on the basis of what it actually cost to create or what it might theoretically cost to recreate. Such costs may bear little similarity to the current value of a brand however

- market-based valuations: when information about market transactions involving comparable brands is available it is possible to estimate one brand's value by comparison with another brand. The facts that such data are scarce and that brands are unique make this an unsatisfactory primary method of valuing a brand. Market comparisons can, however, be useful in testing a primary valuation

- royalty relief method: this is based on the assumption that if a brand has to be licensed from a third-party brand owner, a royalty rate on turnover will be charged for the privilege of using the brand. By owning the brand such royalties are avoided. The royalty relief method involves estimating likely future sales and then applying an appropriate royalty rate to arrive at the income attributable to brand royalties in future years. The stream of notional brand royalty is discounted back to a net present value, the brand value

- economic use method: this method is the most widely used and takes into account the economic value of a brand to the current owner in its current use. Just as analysts now value shares on the basis of 
sustainable cash flows from the business, putting a value on that cash stream, the 'economic use' brand valuation process is essentially a cash-flow valuation.

The focus of the economic use method is on the return earned as a result of owning the brand - the brand's net contribution to the business, both now and in the future. This can be measured by estimating the increase in gross profit attributable to selling a branded rather than an unbranded product or service. Brand valuations, however, are more commonly based on net, 'fully absorbed' profits by identifying the excess net earnings attributable to ownership of the brand. Initially, such valuations were based on a multiple of historical brand earnings, a method used by Financial World, a US financial magazine, which produced an annual estimate of brand values for many years. What is of prime interest, however, is the value of future earnings stemming from the brand's pact with its consumers. It is, therefore, increasingly common for 'economic use' valuations to be based on the discounted value of future brand earnings.

The idea is to take the stream of expected cash flows arising at different times in the future and calculate their value to an investor now through a discounted cash flow (DCF) calculation. The translation of future cash flows into current values is achieved by identifying a discount rate which takes account of the risks inherent in the predicted cash flow. A very risky cash flow, for example the cash flow on sales of Nintendo games, would be discounted much more heavily than the cash flow from a less risky brand, for example Lego bricks. The former is highly volatile, and a sensible investor would mark down the value of the future cash flows, while the latter is likely to be highly reliable.

Using the DCF approach the brand valuer discounts estimated future brand earnings, at an appropriate discount rate, to arrive at a net present value (NPV) - the brand value. Such valuations draw on internal information, supplemented by external market research. They do not consider the value of the brand in use by a different owner or any 'hope value' based on new uses of the brand.

Theoretically, the economic use approach should use pure cash flows from future brand sales. It is more straightforward, however, to use an adjusted profit-and-loss account figure as an approximation of pure cash flow. The approach uses the future earnings stream attributable to a brand after making a fair charge for the tangible assets employed (both maintenance and financing costs). The result is earnings attributable to the intangible assets as a whole. A charge is also normally made for tax at a notional rate. The resulting 'excess' earnings are discounted back to an NPV representing the current value of the brand in question.

Typically, such brand valuations are based on five- to ten-year earnings 
Figure 3: Development of brand evaluation model

\section{Development of brand evaluation model}

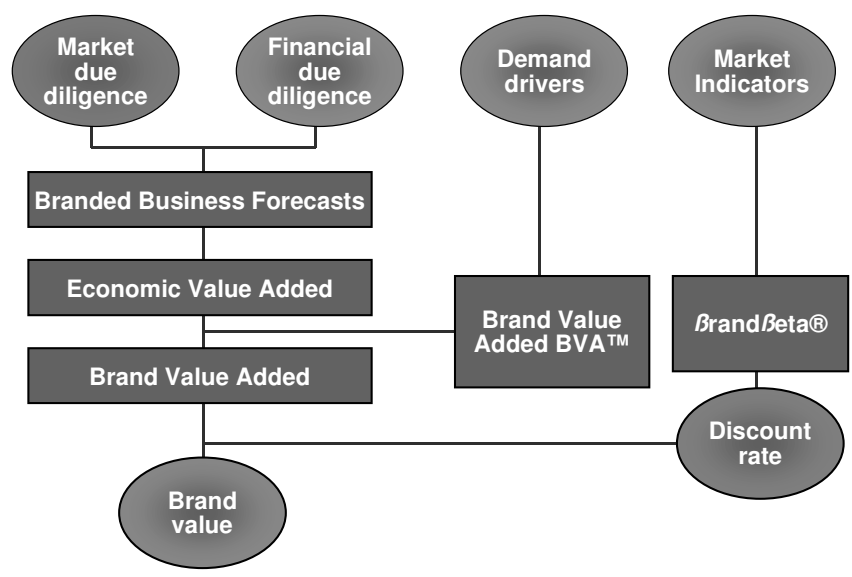

(C)Brand Finance plc

forecasts prepared on an annual basis. In addition, an 'annuity' is calculated on the final year's earnings on the assumption that the brand continues beyond the forecast period, effectively in perpetuity. As brand rights can be owned in perpetuity and many brands have been around for over 50 years this is not an unreasonable assumption in many instances.

A brand valuation typically comprises four elements:

- market analysis (to understand market and competitive conditions)

- brand financial analysis (to identify branded business earnings)

- driver analysis (to determine what proportion of business earnings is attributable to the brand, Brand Value Added BVA ${ }^{\mathrm{TM}}$ )

- brand risk analysis (to assess the security of the brand franchise both with customers and with end consumers - the $\beta \operatorname{rand} \beta$ eta $(\mathbb{)})$.

The process is demonstrated in flowchart form in Figure 3.

\section{THE STEPS IN A BEST-PRACTICE BRAND VALUATION}

A wide range of information is gathered about the brand, its performance and its history from a number of different sources. Data can be collected in a variety of ways including desk research, questionnaires or 
face-to-face interviews. They are then analysed to assess the brand in various terms, beginning with the financial data.

\section{Calculating economic value added}

Once a brand's background and its revenues, costs and capital employed have been established it is possible to produce a five- to ten-year cash flow forecast that can be assessed for reasonableness. Clear definition of the economic value added in the branded business is essential for valuation purposes.

The earnings used to arrive at economic value added must be the fully absorbed earnings of the brand after the allocation of central overhead costs.

- elimination of private label production: the earnings used in the discounted cash flow calculation must relate only to the brand being valued and not to other, unbranded goods which may be produced in parallel with the brand, but which are not sold under the brand name

- remuneration of capital employed: to avoid overvaluation of the brand it is necessary to make a fair charge for the value of the tangible assets employed in the business; for example, the distribution system, the manufacturing plant and the stock. Until a fair return has been made on the fixed assets and working capital tied up in the business it cannot be said that the brand is adding value to the business
- taxation: the discount rate is always applied to post-tax earnings.

The result of this analysis is a thorough assessment of the historic and prospective residual earnings attributable to all the intangible assets employed in the branded business. The next step is to establish what proportion of the total residual earnings relates to the brand as opposed to other intangible assets.

\section{CALCULATING BRAND VALUE ADDED (BVA ${ }^{\mathrm{TM}}$ )}

Different businesses rely in varying degrees on branding to stimulate demand and support price. By identifying what it is that drives demand in the specific market it is possible to estimate the contribution made to the business by the brand. This is typically achieved using a form of trade-off analysis.

This is known as the Brand Value Added BVA ${ }^{\mathrm{TM}}$ Analysis. Although it is a judgmental exercise, it provides a systematised way in which to approach the question and produces reliable conclusions, particularly where it is supported by large sample trade-off or conjoint analysis.

By applying the Brand Value Added $\mathrm{BVA}^{\mathrm{TM}}$ Index to economic value added in the branded business Brand Value Added can be estimated.

\section{ASSESSING BRAND RISK}

A brand value reflects not only the potential of a brand to generate income, but also the likelihood that it 
Figure 4: Example Brandßeta® Scoring Proforma

\begin{tabular}{|l|c|}
\hline Attribute & Score \\
\hline & \\
\hline Time in the market & $(0-10)$ \\
\hline istribution & $(0-10)$ \\
\hline arketshare & $(0-10)$ \\
\hline arket position & $(0-10)$ \\
\hline Sales growth rate & $(0-10)$ \\
\hline Price prem ium & $(0-10)$ \\
\hline E Iasticity ofprice & $(0-10)$ \\
\hline Marketing Spend/ S upport & $(0-10)$ \\
\hline Ad A areness/Effect & $(0-10)$ \\
\hline Brand A wareness/Loyalty & $(0-10)$ \\
\hline & \\
\hline Total & $(0-100)$ \\
\hline
\end{tabular}

(C)Brand Finance plc

will do so. It is, therefore, necessary to determine an appropriate discount rate which takes into account economic, market and brand risks.

The Brand Finance valuation method has an approach to discount rate determination grounded in investment theory. This approach, which was designed to be transparent, objective and reproducible, is known as $\beta \operatorname{rand} \beta$ eta ${ }^{\circledR}$ Analysis.

The starting-point is the risk-free borrowing rate for the geographic market in which the valuation is being completed. This is adjusted to incorporate an equity risk premium. These are available for most stock markets and reflect the expected returns for equity investors in those markets.

The resulting composite discount rate is then adjusted for the risk inherent in the specific sector in which the brand being valued operates. Finally, the average market sector risk rate is either increased or decreased by reference to the specific risk profile of the individual brand to be valued.

$\beta \operatorname{rand} \beta$ eta ${ }^{\circledR}$ Analysis, the final part in the process, considers a small number of objectively verifiable key indicators of brand performance. All brands in the market are scored relative to one another to arrive at the relevant $\beta$ rand $\beta$ eta ${ }^{\circledR}$ for the brand being valued. The scores determine the extent to which the brand-specific discount rate should be above or below the average for the industrial sector and geographic market in which the brand operates. The $\beta \operatorname{rand} \beta$ eta $\AA$ Analysis scoring template is as shown in Figure 4.

Having scored all brands in a given market against the ten objectively 


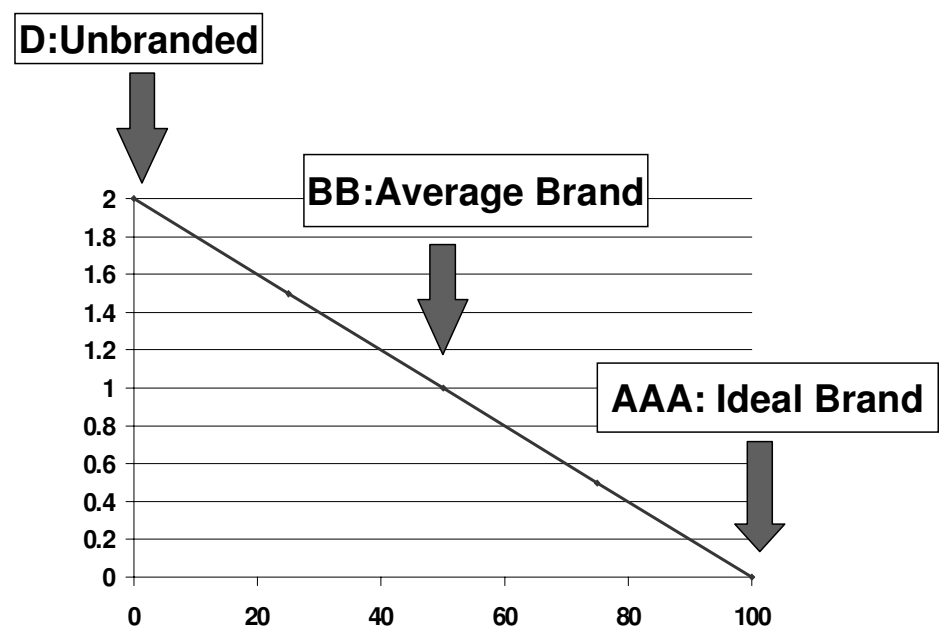

(C)Brand Finance plc

verifiable criteria, brand ratings are determined. These are effectively credit ratings for brands and just as traditional credit rating drives the rates at which banks will lend to corporations the $\beta \operatorname{rand} \beta$ eta ${ }^{\circledR}$ ratings determine the required rate of return implicit in the brand valuation. $\beta \operatorname{rand} \beta$ eta ${ }^{\circledR}$ ratings drive the discount rates used.

An average brand, achieving a $\beta \operatorname{rand} \beta$ eta ${ }^{\circledR}$ score of 50 will attract the average composite discount rate for that sector in that geographic market. A brand scoring 100 is theoretically risk free and is discounted at a risk-free rate. In practice, few if any brands are likely to attract such a rating. A score of 0 attracts the highest discount rate, with a doubling of the equity risk premium. Again this is an unlikely scenario and is likely to apply only to brands in imminent danger of exiting the market (Figure 5).

\section{BRAND VALUE CALCULATED}

Armed with forecast Brand Value Added for the brand, and with a robustly and transparently determined discount rate, brand value is calculated by applying the appropriate discount rate to the expected brand cash flows.

It will be seen in the following simplified example that the starting point is operating earnings calculated in the conventional way.

Capital employed in the operation of the brand is determined and a full charge is made against operating earnings for the finance required to support the brand. The charge for capital 
employed is normally at a risk-free borrowing rate, on the principle that the capital is included at its realisable market value and that no risk is involved in ownership of the capital.

Having made the financing charge, the Economic Value Added in the branded business is left. It is this surplus, after rewarding all factors of production including capital, that can be realistically attributed to the intangible assets at work in the business including the brand.

The total value of the Economic Value Added from the business can be, and usually is, used to calculate the branded business value. One subset of this total value is the brand value alone.

Using the process described above, a Brand Value Added percentage is calculated, this is carried down into the brand valuation calculation.

It will be noted that, in addition to the specific valuation of the first five years of discounted cash flows, an 'annuity' is also included. This is a mathematical summation of all the future earnings beyond the initial valuation period; it reflects the fact that brand earnings can and frequently do continue effectively in perpetuity.

\section{SEGMENTATION AND \\ AGGREGATION OF BRAND \\ VALUES}

Brands have value only in the context of specific marketplaces. In one market the brand may add a great deal of value, in another it may add very little. Consequently, brand valuations are normally segmented by discrete market and then aggregated back to total value. In some markets the brand may even be destroying shareholder value and this should be aggregated into the total valuation as part of the overall segmentation.

Such segmentation brings brand valuation down to the level at which markets and businesses actually operate. It allows a better understanding of where brand value is really being added and from a management point of view allows for modelling of how overall brand value might be increased at aggregate level. It is this which takes brand valuation from the realms of financial reporting into the area of better business management.

\section{TRANSPARENCY AND SUITABILITY}

Brand valuation practices are effective in identifying a clear value of marketing activities and their contribution to building the brand. The brand valuation method used by the author's company is transparent and reproducible. The ability to identify clearly how a brand valuation has been conducted ensures a level of robustness for the figures developed.

The brand valuation concept is, however, still relatively young, and different techniques and methods are adapted to suit individual clients. Dynamic models are used for different sectors and brand valuations can only be improved with experience. 


\section{INTERNAL OR INDEPENDENT?}

Cause for concern may arise, however, if brand valuations are not conducted independently of the organisation. Obviously, problems may arise if the valuers are from within the organisation or, even, if they are outside contractors conducting other projects for the company. In the interest of obtaining a fair and balanced valuation, independent valuers should be used.

Anecdotal evidence has been gathered by the author's company suggesting that auditors have assisted directors to reach valuation estimates; the auditors then, effectively, audit their own figures. This practice blatantly compromises auditors' inde- pendence and should be of grave concern to the ICAEW and other relevant bodies.

\section{STAKEHOLDER HAPPINESS}

Brand valuations are an ideal way to measure the current effectiveness of marketing expenditure. Brand tracking models allow companies to monitor marketing activity and to track progress against set objectives. If brand valuations are conducted regularly, marketing strategies will be developed which lead to greater returns on investment and increased profitability. Companies can then be judged on their success at generating profit, both tangible and intangible. 